\title{
Zooplankton feeding ecology: grazing on phytoplankton and predation on protozoans by copepod and barnacle nauplii in Disko Bay, West Greenland
}

\author{
Jefferson T. Turner ${ }^{1, *}$, Henrik Levinsen ${ }^{2, * *}$, Torkel Gissel Nielsen ${ }^{2}$, \\ Benni Winding Hansen ${ }^{3}$

\footnotetext{
${ }^{1}$ School for Marine Science and Technology, University of Massachusetts Dartmouth, 706 South Rodney French Boulevard, New Bedford, Massachusetts 02744, USA

${ }^{2}$ Department of Marine Ecology, National Environmental Research Institute, Frederiksborgvej 399, PO Box 358, 4000 Roskilde, Denmark

${ }^{3}$ Department of Life Sciences and Chemistry, Roskilde University, PO Box 260, 4000 Roskilde, Denmark
}

\begin{abstract}
Grazing experiments were conducted with Calanus spp. and Balanus cf. crenatus nauplii incubated with natural plankton from Disko Bay, West Greenland during the post-spring-bloom period. Both copepod and barnacle nauplii were feeding on different types of protists although at different rates. Calanus spp. nauplii preferred large ciliates and dinoflagellates whereas flagellates $\sim 5 \mu \mathrm{m}$ in diameter and Myrionecta rubra were hardly ingested at all. B. cf. crenatus nauplii preferred diatoms and also consumed the small flagellates at relatively high rates. Compared to Calanus spp. nauplii, $B$. cf. crenatus nauplii ingested ciliates and dinoflagellates at low rates suggesting a more herbivorous feeding mode than the more predaceous copepod nauplii. The daily grazing impact of the nauplii community in Disko Bay was estimated using the weight-specific mean clearances from the grazing experiments and field biomass values of different categories of prey and nauplii. These calculations showed that the grazing impact by the nauplii community on all prey categories was generally modest (1.3 to $9.2 \%$ ). However, the dominant part of the total food intake by Calanus spp. nauplii in the surface water was composed of ciliates and dinoflagellates, most of which were phagotrophic
\end{abstract}

KEY WORDS: Nauplii $\cdot$ Copepod $\cdot$ Barnacle $\cdot$ Grazing $\cdot$ Predation $\cdot$ Arctic $\cdot$ Greenland

\section{INTRODUCTION}

The nauplius is the initial developmental stage of most crustaceans after the egg, and as such, nauplii are extremely abundant in the marine zooplankton. Copepod nauplii are arguably the most numerous form of metazoans on the planet (Björnberg 1984), with the possible exception of nematodes. When appropriate fine meshes of plankton nets are employed, copepod

\footnotetext{
*E-mail: jturner@umassd.edu

${ }^{* *}$ Present address: Freshwater Biological Laboratory, University of Copenhagen, 51 Helsingørsgade, 3400 Hillerød, Denmark
}

nauplii usually outnumber later copepodite and adult stages of copepods by several orders of magnitude (Turner 1982, 1994, Webber \& Roff 1995, Hansen et al. 1999). Nauplii of other crustaceans, including meroplankton such as barnacle nauplii can also become sporadically abundant (Lang \& Ackenhusen-Johns 1981). Copepod and barnacle nauplii are important prey of fish larvae and other planktonic predators, but the feeding ecology of these nauplii is poorly known (Turner 1984, 2000). Since copepod nauplii can ingest pico- and nanophytoplankton (Uye \& Kasahara 1983, Berggreen et al. 1988) as well as some forms of bacterioplankton (Turner \& Tester 1992, Roff et al. 1995), 

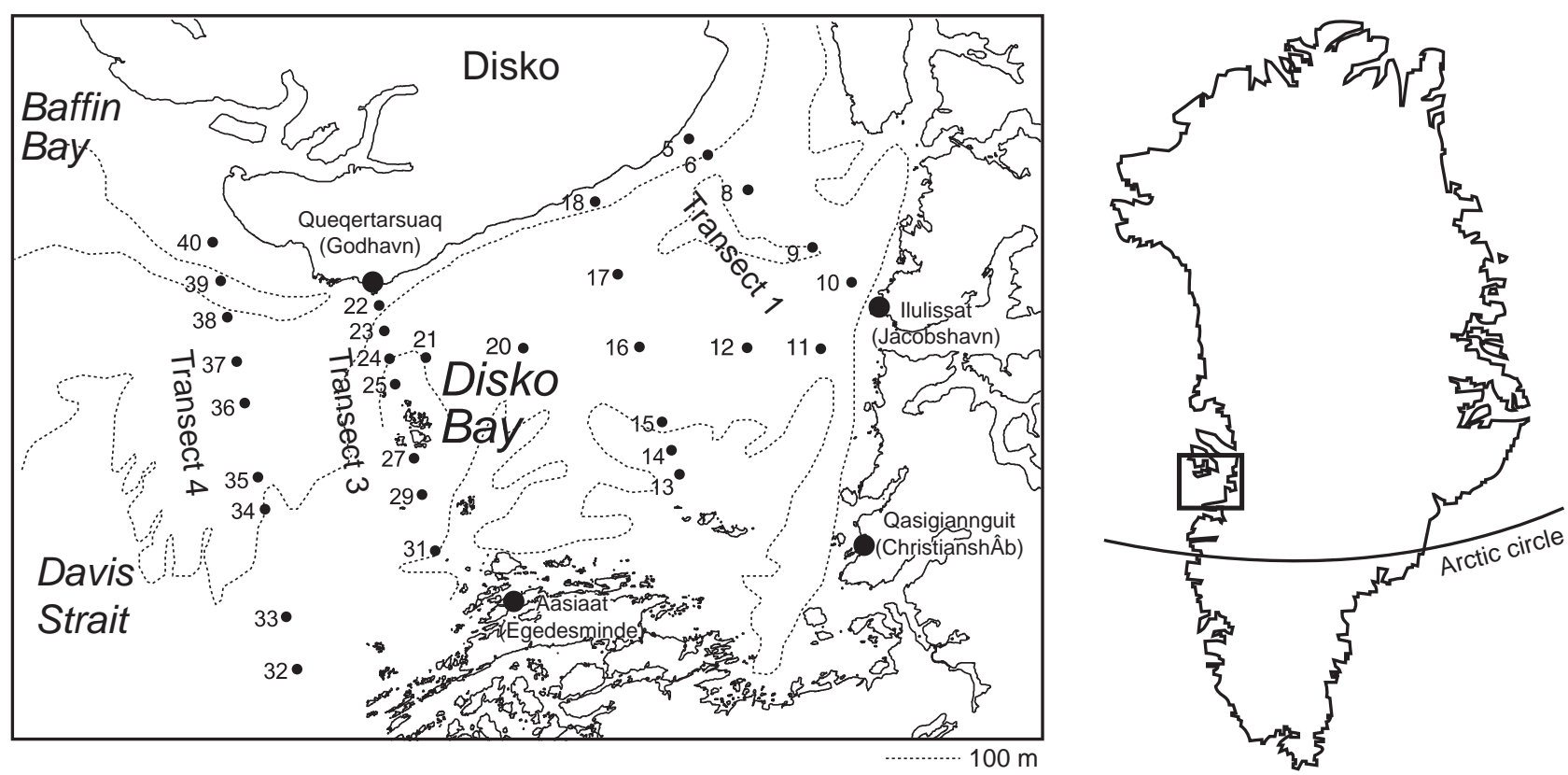

Fig. 1. Map of Disko Bay, West Greenland, showing the sampling stations visited during the cruise. Transect 4 covers Disko Bank (dotted line represents $100 \mathrm{~m}$ isobath), Transect 5 consisted of Stns 11, 12, 16, 20, 21, 24, 37

they may serve as important linkages between the microbial and classical food webs (Turner \& Roff 1993). This may especially be true in Arctic systems like Disko Bay and other high-latitude regions where large populations of Calanus spp. descend as late-stage copepodites into deep water for overwintering during the post spring bloom period well before the productive season ends, leaving nauplii, copepodites and protozoans as primary grazers (Hansen et al. 1999, Madsen et al. 2001).

Most of the limited information on feeding, growth and development by copepod nauplii comes from experimental or rearing studies where laboratory cultured phytoplankton were offered as food (reviewed by Turner 1984, Kiørboe \& Sabatini 1995). A few studies have confirmed that copepod nauplii ingest ciliates from monospecific cultures (Stoecker \& Egloff 1987) or quasi-natural assemblages of estuarine phytoplankton and microzooplankton in mesocosms (Merrel \& Stoecker 1998). There is, however, little information on naupliar predation on ciliates and other protozoans in natural mixed assemblages more typical of offshore waters (we use the term 'protozoans' to distinguish phagotrophic and/or mixotrophic protists such as ciliates and non-pigmented dinoflagellates from eucaryotic autotrophic phytoplankters, which are also 'protists': see Levinsen et al. 1999). Although there have been a few studies of growth rates of copepod nauplii feeding upon natural food suspensions (McKinnon 1996, Hopcroft \& Roff 1998), we are unaware of any published studies of the comparative feeding by cope- pod nauplii on various components of natural mixed assemblages of phytoplankton and protozoans. We know of no information on feeding by planktonic barnacle nauplii beyond the feeding studies on cultured algal diets by Moyse (1963) and Stone (1989), and a handful of studies of barnacle rearing on cultured phytoplankton diets referenced in Lang (1979), Turner (1984) and Anderson (1994). Accordingly, we examined feeding by abundant copepod (Calanus spp.) and barnacle (B. cf. crenatus) nauplii on natural phytoplankton and protozoan suspensions at in situ concentrations.

\section{MATERIALS AND METHODS}

The study was conducted in Disko Bay, West Greenland in June 1997 during a cruise with the RV 'Adolf Jensen' (Greenland Institute for Natural Resources). Sampling was done along 4 transects covering stations from near Ilulissat Icefjord and Vaigat (Transect 1) to the Disko Bank area, which separates Disko Bay from Baffin Bay (Transect 4). An additional transect was partly based on stations visited on these 4 transects. This Transect 5 transversed the central bay from Ilulissat Icefjord to Disko Bank at the mouth of the bay (Fig. 1).

Nauplii for the grazing experiments were collected from the upper $\sim 30 \mathrm{~m}$ by a WP-2 net with a mesh size of $200 \mu \mathrm{m}$, fitted with a large non-filtering cod-end. Copepod nauplii were Calanus finmarchicus and/or $C$. glacialis, which are the primary calanoid copepods that 
Table 1. Calanus spp. (=C. finmarchicus + C. glacialis) and Balanus cf. crenatus nauplii grazing experiments conducted in Disko Bay, West Greenland, June 1997. L = mean length $( \pm \mathrm{SD})$ and $\mathrm{W}=$ mean weight of individuals from the 3 replicate grazing bottles in each experiment combined. Length measurements were conducted on Lugol-fixed individuals from all 3 replicates after each experiment ( $\mathrm{n}=52 \pm 5$ for Calanus nauplii and $14 \pm 8$ for $B$. cf. crenatus nauplii). Only Calanus spp. nauplii $>$ NIII were measured, since stages < NIII do not feed. Weight-specific clearances were calculated using the mean weights of separate replicates. Calanus spp. nauplii weights were calculated by using length-weight equations for C. finmarchicus nauplii (Hygum et al. 2000). $B$. cf crenatus nauplii weights were calculated by establishing an equation of the form $\log C=a \log (L)-b$ from the 2 lengthweight values in Uye (1982), where $C=$ carbon weight $(\mu \mathrm{g}), \mathrm{L}=$ length $(\mu \mathrm{m})$, and $\mathrm{a}, \mathrm{b}=$ constants

\begin{tabular}{|c|c|c|c|c|c|c|c|c|}
\hline Expt & Stn & Date & Nauplii & Nauplii ml $\mathrm{l}^{-1}$ & $\mathrm{~L}(\mu \mathrm{m})$ & $\mathrm{W}(\mu \mathrm{g} C)$ & Duration (h) & $\mathrm{T}\left({ }^{\circ} \mathrm{C}\right)$ \\
\hline I & 24 & $14-16$ & Calanus & $0.10-0.14$ & $600 \pm 95$ & 2.8 & 47 & $5 \pm 1$ \\
\hline IIa & 32 & $15-16$ & Calanus & $0.04-0.22$ & $680 \pm 95$ & 4.8 & 23 & $5 \pm 2$ \\
\hline IIb & 32 & $15-16$ & Balanus & 0.03 & $735 \pm 40$ & 9.8 & 23 & $5 \pm 2$ \\
\hline IIIa & 33 & $15-16$ & Calanus & $0.08-0.22$ & $665 \pm 110$ & 4.4 & 23 & $5 \pm 2$ \\
\hline IIIb & 33 & $15-16$ & Balanus & 0.03 & $750 \pm 35$ & 10.5 & 23 & $5 \pm 2$ \\
\hline IVa & 35 & $15-16$ & Calanus & $0.11-0.14$ & $645 \pm 285$ & 3.8 & 24 & $5 \pm 2$ \\
\hline $\mathrm{IVb}$ & 35 & $15-16$ & Balanus & 0.03 & $760 \pm 30$ & 11.1 & 24 & $5 \pm 2$ \\
\hline
\end{tabular}

are reproductive in the upper strata of Disko Bay during this period (Hansen et al. 1999, Madsen et al. 2001). Barnacle nauplii were Balanus cf. crenatus. After sorting nauplii into petri dishes placed on ice, either 60 Calanus spp. or 20 (B. cf. crenatus) were added to triplicate experimental incubations with $600 \mathrm{ml}$ aliquots of natural food suspensions in acid-washed polycarbonate bottles. Water for incubations was collected from the depth of the fluorescence maximum (20 to $30 \mathrm{~m}$ ) with a Niskin bottle and screened through a $200 \mu \mathrm{m}$ plankton net by reverse filtration in order to exclude most extraneous metazoan grazers without removing chainforming diatoms and larger phytoplankton and protozoan cells. Other triplicate bottles were immediately fixed in acid Lugol solution ( $2 \%$ final concentration) to determine the initial phytoplankton and protozoan concentrations. Triplicate controls (without nauplii) were incubated together with experimental suspensions (with added nauplii) usually for $\sim 1 \mathrm{~d}$ (Table 1). Incubations were carried out at in situ temperatures in a container with flow-through surface water and bottles were rotated intermittently by hand. The temperature was recorded by a temperature logger every $3 \mathrm{~min}$. At the end of the incubations, controls and experimental suspensions were preserved for subsequent microscopic counting of remaining phytoplankton and protozoans. Subsamples for determination of chlorophyll a (chl a) were also taken; triplicate $200 \mathrm{ml}$ aliquots were filtered through $\mathrm{GF} / \mathrm{F}$ filters and dark-extracted in ethanol before measurement on a Turner fluorometer (Jespersen \& Christoffersen 1987).

Concentrations of phytoplankton, ciliates, and dinoflagellates were determined using the same procedures as described in Levinsen et al. (2000a). Phytoplankton in preserved aliquots were concentrated by sedimentation and counted at $200 \times$ or $400 \times$ in Sedgwick-Rafter cells with conventional phase-contrast microscopy. Ciliates and dinoflagellates were concentrated by sedimentation in $50 \mathrm{ml}$ Utermöhl chambers and counted by inverted microscopy with phase-contrast at $100 \times$ or $200 \times$. Identified species and morpho-types were pooled into size classes of phytoplankton, ciliates or dinoflagellates. Cell volumes for all these classes, except for diatoms, were estimated from measurements of linear dimensions assuming simple geometric shapes of cells, and converted to organic $\mathrm{C}$ content using a relation of $0.13 \mathrm{pg} \mathrm{C}$ $\mu^{-3}$ (Hansen et al. 1997). Diatom plasma volume was determined and converted to organic $\mathrm{C}$ according to Strathmann (1967).

It is difficult to distinguish autotrophic and mixotrophic dinoflagellates from heterotrophic dinoflagellates using light microscopy and Lugol preserved samples. The best procedure for this is epifluorescence microscopy on gluteraldehyde-fixed samples. Absence of fluorescence from chlorophyll indicates that cells are non-pigmented and therefore heterotrophic (see Levinsen et al. 1999 and references therein). Levinsen et al. (2000b) compared abundances of non-pigmented heterotrophic dinoflagellates and pigmented autotrophic or mixotrophic dinoflagellates from Disko Bay over the annual cycle, including the period of the present investigation, using light and epifluorescence microscopy. Using these techniques, it was found that the dominant athecate gymnodinoid dinoflagellates of the genera Gymnodinium and Gyrodinium were usually non-pigmented. Since many pigmented dinoflagellates are also able to engulf particulate prey, these taxa were all considered to be phagotrophic protists or 'protozoans' in the present study.

Grazing experiments were conducted at 4 stations with Calanus spp. and at 3 stations with (Balanus cf. crenatus) nauplii (Table 1). Clearance and ingestion were calculated according to Frost (1972) for feeding upon chl $a$, nanoflagellates, diatoms and the photosynthetic ciliate Myrionecta rubra (=Mesodinium rubrum), as well as for feeding upon oligotrichous ciliates and 

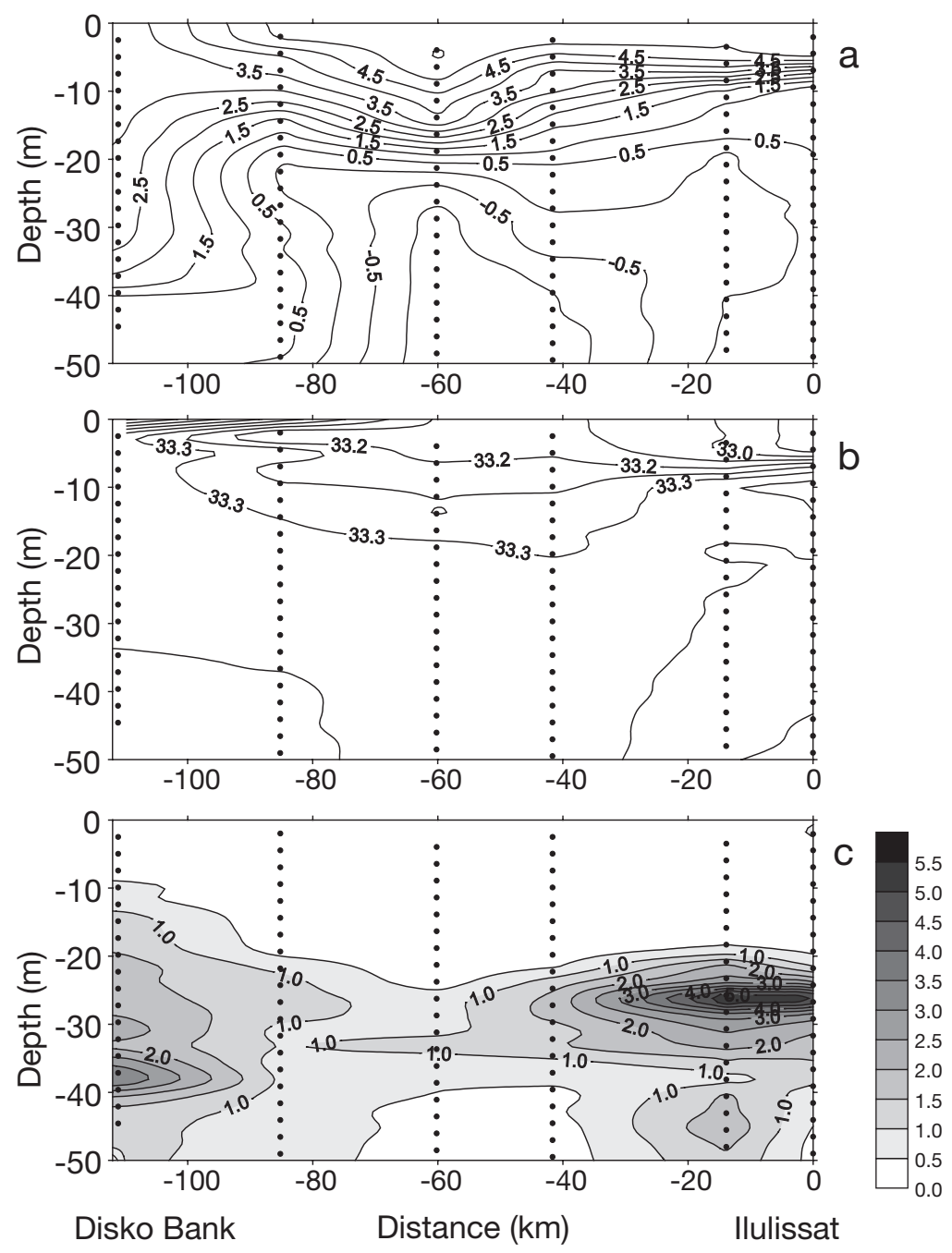

Fig. 2. (a) Temperature, ${ }^{\circ} \mathrm{C}$, (b) salinity and (c) chlorophyll a relative fluorescence (arbitrary units), along Transect 5 (0 to $50 \mathrm{~m}$ )

athecate dinoflagellates smaller or larger than $20 \mu \mathrm{m}$. Cell concentrations from triplicate initial and control bottles in each experiment were averaged before calculation of the clearance. The standard error of the clearance for the different food components therefore represents the variation among the 3 replicate grazing bottles. Carbon ingestion was obtained from the product of the number of cells of a particular cell category ingested and the weighted mean $\mathrm{C}$ content for that cell category in the initial bottles. Total ingestion was the sum of the different prey categories ingested.

During addition of nauplii to the grazing bottles there was the possibility that individuals might remain stuck in the pipette, thus biasing nauplii concentrations from the intended values of 60 grazing nauplii per bottle. Therefore, the actual concentrations of nauplii counted in Lugol fixed sub-samples from the experimental suspensions after incubation were used in the grazing calculations. For Calanus spp. nauplii, each counted individual was staged (NI and NII, NIII and NIV or NV and NVI) and the weight estimated using the length-weight relations for $C$. finmarchicus provided by Hygum et al. (2000). The most dominant copepod nauplii in the grazing experiments were Stages NV and NVI. Stages of Calanus spp. nauplii younger than NIII were rare and were neglected from clearance calculations, as these do not feed (Marshall \& Orr 1955, Williams et al. 1987). All Balanus cf. crenatus added to experimental bottles were nauplii at the time of addition, but a few ( $<5 \%$ ) developed into cyprid larvae during incubation. Visual inspection of bottles prior to preservation revealed actively swimming copepod and barnacle nauplii, so nauplii mortality was considered insignificant and was calculated as zero. The weight-specific clearance $\left(\mathrm{ml} \mu \mathrm{g} \mathrm{C}^{-1} \mathrm{~d}^{-1}\right)$ of Calanus spp. and B. cf. crenatus nauplii was estimated using the mean nauplii carbonweight in each grazing replicate.

Field estimates of chl a concentrations and the biomass of ciliates and dinoflagellates from the surface water in Disko Bay were determined using the same procedures as described above except that fractionated chl a was also determined by filtration through 10 and $45 \mu \mathrm{m}$ mesh-size plankton nets. Calanus spp. and Balanus cf. crenatus nauplii field abundance and biomass in the upper $50 \mathrm{~m}$ was estimated from depth-integrated samples collected by a submersible pump equipped with a flow meter (Digital Model 438 100, Hydro-Bios Kiel). Collected samples were concentrated from a large non-filtering codend and preserved in buffered formalin ( $2 \%$ final concentration). Lengths of at least 50 nauplii per sample were measured and converted to biomass based on length-weight regressions (Hygum et al. 2000).

\section{RESULTS}

The entire area of Disko Bay was stratified, with warmer temperatures and reduced salinity in the upper strata due to melt water (Fig. 2a,b). A distinct fluorescence maximum at a depth of 20 to $40 \mathrm{~m}$ also characterized the bay (Fig. 2c). This structure of the water column is typical for Disko Bay during the post spring bloom stratified summer period (Nielsen \& Hansen 1999).

$\mathrm{Chl} a$ at the surface $(2.5 \mathrm{~m})$ from stations along the transects ranged from a total of 0.1 to $4.7 \mu \mathrm{g} \mathrm{l}^{-1}$, with most in the $>45$ and $<10 \mu \mathrm{m}$ size fractions (Fig. 3). 

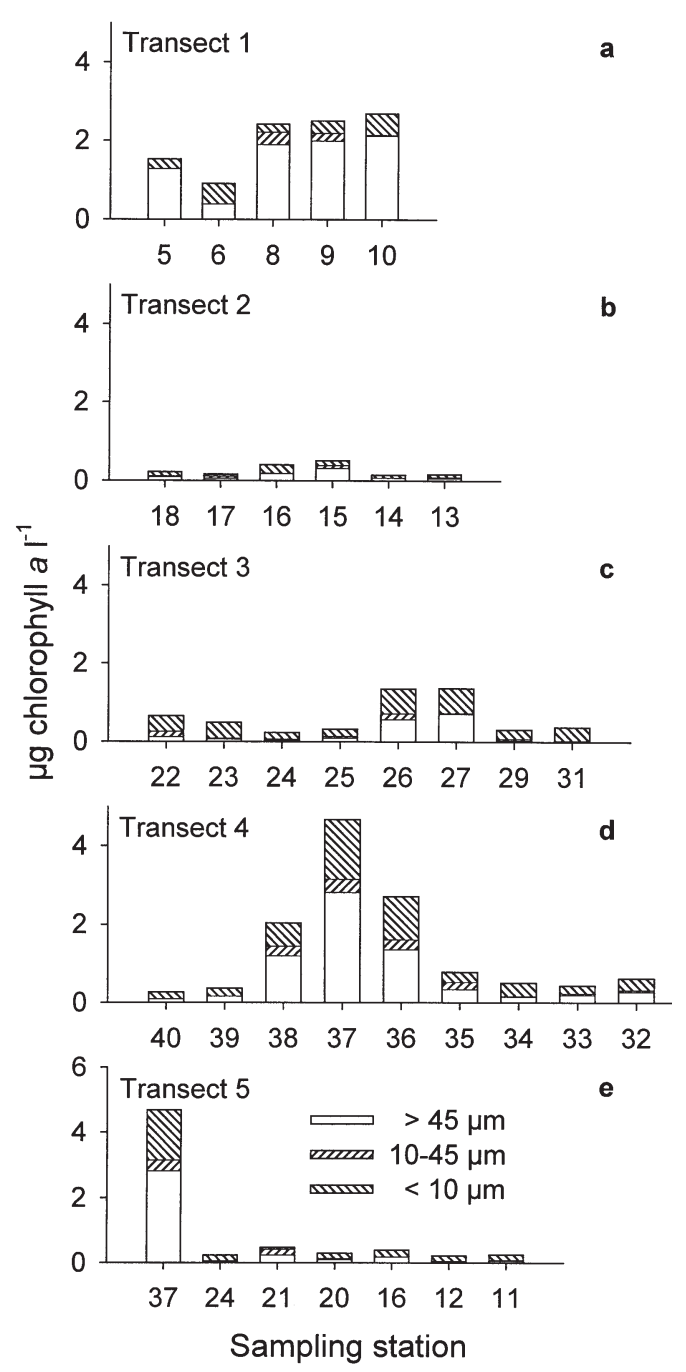

Fig. 3. Phytoplankton concentrations at $2.5 \mathrm{~m}$ depth measured as size-fractionated chlorophyll $a$ along Transects 1 to 5

Ciliate and dinoflagellate biomass from selected stations ranged from 0.7 to 5.6 and 3.4 to $24.0 \mu \mathrm{g} \mathrm{C}^{-1}$, respectively (Fig. 4). Biomass of dinoflagellates was generally higher than that of ciliates, with $>20 \mu \mathrm{m}$ sized cells dominating.

Nauplii biomass of Calanus spp. and Balanus cf. crenatus ranged from 0.9 to 19.3 and 0 to $7.5 \mu \mathrm{g} \mathrm{C} \mathrm{l}^{-1}$, respectively (Fig. 5). Most Calanus spp. nauplii were Stages NIII or NIV and NV or NVI of C. finmarchicus, with lesser contributions by the same stages of $C$. glacialis.

Over an experimental range of natural mean chl a concentrations of 1.5 to $6.2 \mathrm{\mu g} \mathrm{l}^{-1}$ (Fig. 6a), rates of chl a clearance averaged 1.3 to $4.9 \mathrm{ml}$ ind..$^{-1} \mathrm{~d}^{-1}$ for Calanus spp. nauplii (Fig. 6b), and 0.8 to $6.7 \mathrm{ml}$ ind. ${ }^{-1} \mathrm{~d}^{-1}$ for Balanus cf. crenatus nauplii (Fig. 6c).

While feeding on natural phytoplankton assemblages with a concentration range of 55.7 to 136.0 cells $\mathrm{ml}^{-1}$ (Fig. 7a), most of which were $\sim 5 \mu \mathrm{m}$ chlorophyll- bearing nanoflagellates (Levinsen et al. 2000a), rates of clearance of Thalassiosira spp.-dominated diatoms $\sim 20 \mu \mathrm{m}$ in size by Calanus spp. nauplii were 4.8 to $11.6 \mathrm{ml}$ ind. ${ }^{-1} \mathrm{~d}^{-1}$ (Fig. $7 \mathrm{c}$ ), and 8.4 to $32.6 \mathrm{ml}$ ind. ${ }^{-1} \mathrm{~d}^{-1}$ by Balanus cf. crenatus nauplii (Fig. $7 \mathrm{~d}$ ). Clearance of nanoflagellates by Calanus spp. nauplii was low (1.6 to $1.8 \mathrm{ml}$ ind..$^{-1} \mathrm{~d}^{-1}$ ), and half the experiments gave negative values, since nanoflagellate growth during incubations exceeded removal by grazing (Fig. 7c). Clearance of nanoflagellates by $B$. cf. crenatus nauplii averaged 4.8 to $36.0 \mathrm{ml}$ ind..$^{-1} \mathrm{~d}^{-1}$ (Fig. $7 \mathrm{~d}$ ).

At mean initial concentrations of 0.8 to 6.1 Myrionecta rubra $\mathrm{ml}^{-1}, 1.3$ to 2.6 oligotrichous ciliates $<20 \mu \mathrm{m}$ $\mathrm{ml}^{-1}$, and 1.3 to 4.1 oligotrichous ciliates $>20 \mu \mathrm{m} \mathrm{ml}^{-1}$ (Fig. 8a), in which the biomass was dominated by the latter (Fig. 8b), clearance of oligotrichous ciliates by Calanus spp. nauplii was much greater than clearance of M. rubra (Fig. 8c). Similarly, Balanus cf. crenatus nauplii generally exhibited higher clearance of oligotrichous ciliates than of $M$. rubra, although some calculated clearances were negative (Fig. 8d).

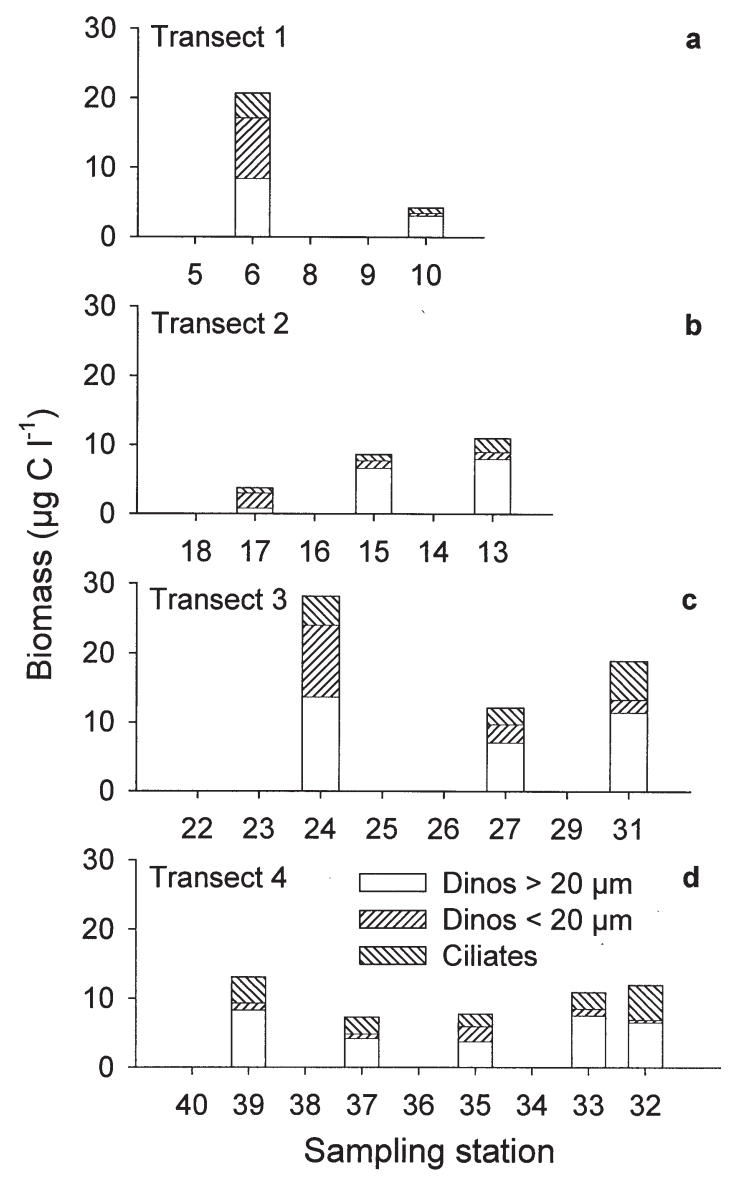

Fig. 4. Protozoan biomass at $2.5 \mathrm{~m}$ depth at selected stations along Transects 1 to 4 . Protozoans include dinoflagellates and ciliates. Stations with no data shown are those at which protozoans were not counted, not stations for which protozoan biomass was zero 

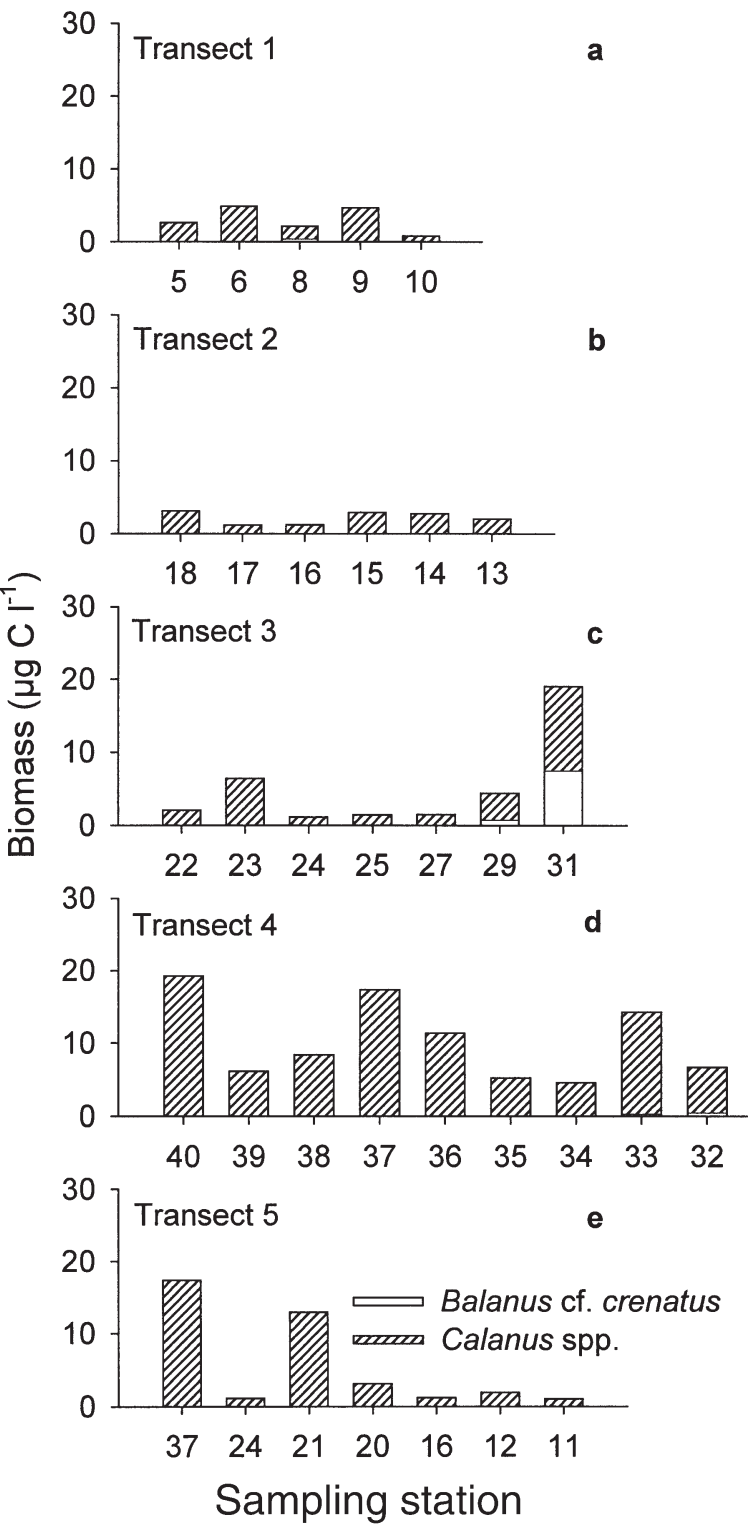

Fig. 5. Calanus spp. and Balanus cf. crenatus nauplii biomass values (means for 0 to $50 \mathrm{~m}$ ) along Transects 1 to 5

Over a natural mean abundance range of 6.5 to 15.1 dinoflagellates $\mathrm{ml}^{-1}$ (Fig. 9a), in which abundance was dominated by athecate cells $<20 \mu \mathrm{m}$ (Fig. 9a), but biomass was dominated by athecate cells $>20 \mu \mathrm{m}$ (Fig. 9b), the mean clearance rate by Calanus spp. nauplii was highest on the larger cell sizes (Fig. 9c). Clearance of dinoflagellates by Balanus cf. crenatus nauplii was more variable (Fig. 9d).

Weight-specific mean clearance rates for Calanus spp. nauplii reveal different amounts of feeding upon different components of natural food suspensions (Table 2). While chl $a$ and diatoms were clearly grazed, nanoflagellates generally were not. Among the larger protists, Myrionecta rubra was only slightly consumed,

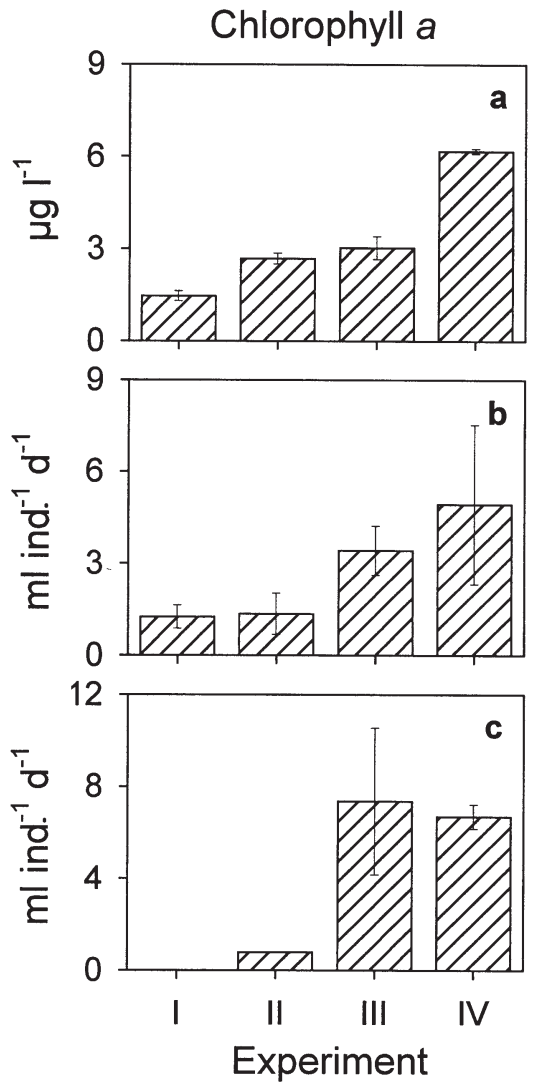

Fig. 6. (a) Initial concentrations of chlorophyll $a_{\text {, (b) clearances }}$ on chlorophyll a by nauplii of Calanus spp. and (c) Balanus cf. crenatus. Error bars represent standard errors of the mean. Note different scales on $y$-axis for (b) and (c)

whereas athecate dinoflagellates, particularly those $>20 \mu \mathrm{m}$, were eaten at higher rates. By far the highest clearances by Calanus spp. nauplii were when feeding on oligotrichous ciliates.

Weight-specific clearance rates for barnacle nauplii were different from those of copepod nauplii (Table 2). Balanus cf. crenatus nauplii displayed higher clearance of diatoms and nanoflagellates than Calanus spp. nauplii, but clearance of oligotrichous ciliates was lower. Clearance of dinoflagellates by $B$. cf. crenatus nauplii was also lower than by Calanus spp. nauplii. Considering that $B$. cf. crenatus nauplii have a higher biomass (10.4 \pm SD $1.9 \mu \mathrm{g} \mathrm{C}$ ind..$\left.^{-1}\right)$ than Calanus spp. nauplii (2.8 to $4.8 \mu \mathrm{g} \mathrm{C}$ ind. ${ }^{-1}$ : Table 1), these disparities become even more marked, emphasizing the generally herbivorous feeding mode of barnacle nauplii and the substantial predation of copepod nauplii upon oligotrichous ciliates, and dinoflagellates, most of which were phagotrophic (Levinsen et al. 2000b).

Ingestion by Calanus spp. nauplii based on clearance measurements and mean concentrations of the different prey categories was 1.9 to $22.2 \mathrm{ng} \mathrm{chl} a$ ind. $.^{-1} \mathrm{~d}^{-1}, 4.2$ to 48.7 ng phytoplankton $\mathrm{C}_{\text {ind }}{ }^{-1} \mathrm{~d}^{-1}, 0$ to $0.9 \mathrm{ng}$ Myrionecta 

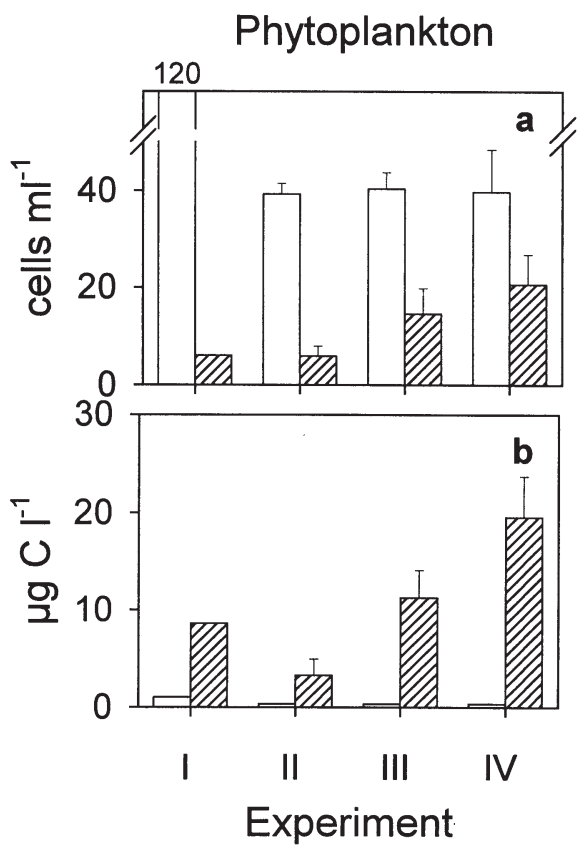

\section{Nanoflagellates $\sim 5 \mu \mathrm{m}$}

Phytoplankton
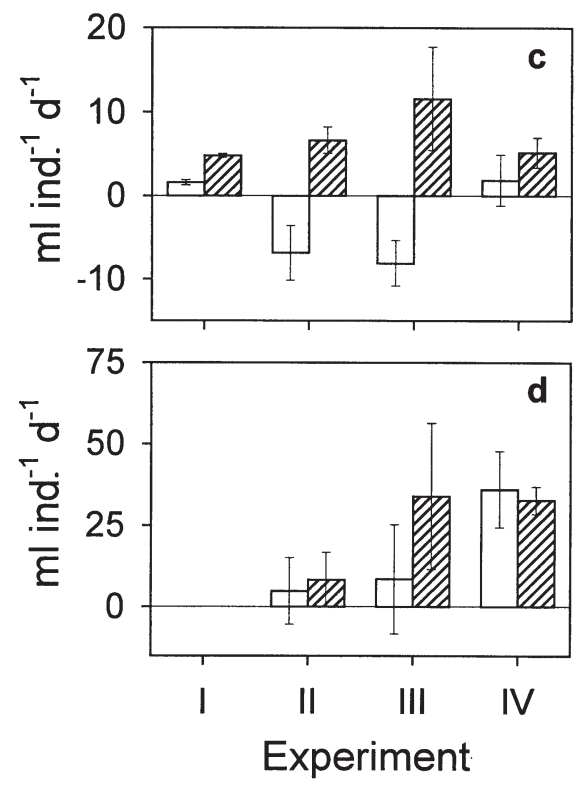

एवiा? Diatoms

Fig. 7. (a) Initial concentrations and (b) biomass of the dominant phytoplankton groups and clearance of diatoms and nanoflagellates by nauplii of (c) Calanus spp. and (d) Balanus cf. crenatus. Diatoms consisted of Thalassiosira spp. and Chaetoceros spp.; nanoflagellates were dominated by cells with a diameter of $\sim 5 \mu \mathrm{m}$. Error bars represent standard errors of the mean. Note different scales on $y$-axis for (c) and (d)

rubra $\mathrm{C}$ ind ${ }^{-1} \mathrm{~d}^{-1}, 4.8$ to 10.3 ng ciliate $\mathrm{C}$ ind.$^{-1} \mathrm{~d}^{-1}$ and 5.1 to $11.8 \mathrm{ng}$ dinoflagellate $\mathrm{C}$ ind.$^{-1} \mathrm{~d}^{-1}$ (Fig. 10a-d). Balanus cf. crenatus nauplii ingested these prey categories at rates of $2.4-39.8,7.5-260,0-2.7,0-23.2$ and $0-47 \mathrm{ng}$ ind. ${ }^{-1} \mathrm{~d}^{-1}$ (Fig. 10e-h). Total daily ingestion of Calanus spp. nauplii ranged from 20.2 to $67.8 \mathrm{ng} \mathrm{C}$ ind. ${ }^{-1} \mathrm{~d}^{-1}$ and $B$. cf. crenatus nauplii consumed between 54.9 and $294.6 \mathrm{ng} \mathrm{C}$ ind..$^{-1} \mathrm{~d}^{-1}$.

What was the daily grazing impact of field populations of copepod and barnacle nauplii upon various components of prey assemblages in Disko Bay? Using weight-specific mean clearances of prey categories obtained in the grazing experiments (Table 2), and field biomass in Disko Bay of these prey categories (phytoplankton biomass converted from chl $a$ in Fig. 3, ciliate and dinoflagellate biomass as in Fig. 4) as well as for copepod and barnacle nauplii (Fig. 5), it is possible to obtain a rough estimate of: (1) percent clearance of the surface water on specific prey categories, (2) values for ingestion (Table 3), and (3) relative ingestion of protozoans versus phyto- plankton by copepod and barnacle nauplii (Table 4). In general, grazing on phytoplankton and predation on protozoans accounted for only a few percent of the standing stock of a particular prey category (Table 3). In grazing experiments, where the water for food suspensions was collected from the fluorescence maximum depth, calculated ingestion of protozoans accounted for a minor fraction of the total ingestion (Table 5). However, when weight-specific mean clearances calculated from grazing experiments were applied to assemblages in surface waters, which had lower chl a concentrations, the calculated proportion of ingestion of protozoans was much greater (Table 4).

\section{DISCUSSION}

The comparatively higher predation of copepod nauplii on protozoans than on co-occurring phytoplankton in natural mixed assemblages appears to be previously undocumented. However, it should not be surprising, considering the increasing evidence that many adult copepods also feed

Table 2. Calanus spp. and Balanus cf. crenatus. Weight-specific clearances $\left(F_{\text {spec }}, \mathrm{ml} \mu \mathrm{g} \mathrm{C} \mathrm{C}^{-1} \mathrm{~d}^{-1}\right)$ at $5^{\circ} \mathrm{C}$ for nauplii preying on chlorophyll $a$ and different groups of protists. $\mathrm{n}=$ total number of replicates of all experiments

\begin{tabular}{|c|c|c|c|c|c|c|}
\hline \multirow[t]{2}{*}{ Prey } & \multicolumn{3}{|c|}{ Calanus spp. nauplii } & \multicolumn{3}{|c|}{ Balanus nauplii } \\
\hline & $F_{\text {spec }}$ & (SE) & $\mathrm{n}$ & $F_{\text {spec }}$ & $(\mathrm{SE})$ & $\mathrm{n}$ \\
\hline Chlorophyll a & 0.68 & $(0.20)$ & 23 & 0.43 & $(0.14)$ & 11 \\
\hline \multicolumn{7}{|l|}{ Phytoplankton } \\
\hline Autotrophic flagellates $\sim 5 \mu \mathrm{m}$ & -0.47 & $(0.46)$ & 12 & 1.52 & $(0.76)$ & 9 \\
\hline Diatoms $^{\mathrm{a}}$ & 1.94 & $(0.41)$ & 12 & 2.34 & $(0.77)$ & 9 \\
\hline Total & -0.23 & $(0.48)$ & 12 & 1.49 & $(0.67)$ & 9 \\
\hline \multicolumn{7}{|l|}{ Ciliates } \\
\hline Myrionecta rubra & 0.04 & $(0.19)$ & 12 & -0.21 & $(0.33)$ & 9 \\
\hline Oligotrichous ciliates $<20 \mu \mathrm{m}$ & 3.09 & $(0.47)$ & 12 & 0.65 & $(0.71)$ & 9 \\
\hline Oligotrichous ciliates $>20 \mu \mathrm{m}$ & 5.28 & $(0.89)$ & 12 & 1.56 & $(0.71)$ & 9 \\
\hline Total & 1.25 & $(0.35)$ & 12 & 0.06 & $(0.32)$ & 9 \\
\hline \multicolumn{7}{|l|}{ Dinoflagellates } \\
\hline Athecate dinoflagellates $<20 \mu \mathrm{m}$ & 1.05 & $(0.17)$ & 12 & 0.55 & $(0.28)$ & 9 \\
\hline Athecate dinoflagellates $>20 \mu \mathrm{m}$ & 1.94 & $(0.27)$ & 12 & 0.71 & $(0.31)$ & 9 \\
\hline Total & 1.19 & $(0.15)$ & 12 & 0.61 & $(0.25)$ & 9 \\
\hline
\end{tabular}



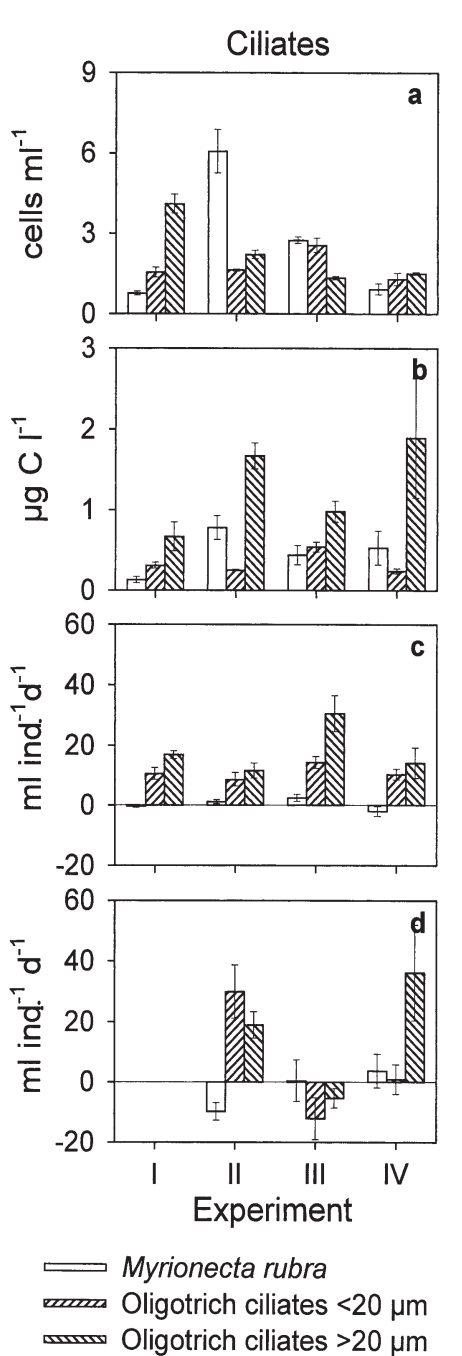

Fig. 8. (a) Initial concentrations and (b) biomass of Myrionecta rubra, nano- $(<20 \mu \mathrm{m})$ and micro- $(>20 \mu \mathrm{m})$ sized oligotrich ciliates and clearance of these ciliate groups by nauplii of (c) Calanus spp. and (d) Balanus cf. crenatus. Error bars represent standard errors of the mean
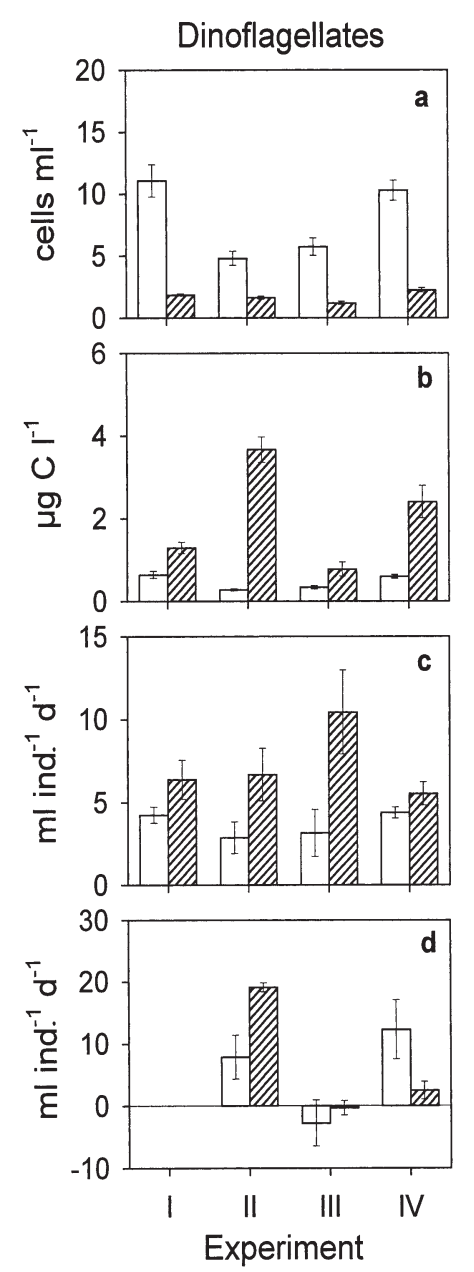

Athecate $<20 \mu \mathrm{m}$ Athecate $>20 \mu \mathrm{m}$

Fig. 9. (a) Initial concentrations and (b) biomass of nano- $(<20 \mu \mathrm{m})$ and micro- $(>20 \mu \mathrm{m})$ sized athecate dinoflagellates and clearance of these dinoflagellate size-groups by nauplii of (c) Calanus spp. and (d) Balanus cf. crenatus. Error bars represent standard errors of mean.

Note different scales on $y$-axis extensively upon phagotrophic ciliates and dinoflagellates (Tiselius 1989, Wiadnyana \& Rassoulzadegan 1989, Gifford \& Dagg 1991, Jonsson \& Tiselius 1990, Stoecker \& Capuzzo 1990, Pierce \& Turner 1992, Turner \& Granéli 1992, Fessenden \& Cowles 1994, Nakamura \& Turner 1997, Levinsen et al. 2000a, Turner 2000). Together with information that nauplii of certain copepod species can be both bacterivorous (Turner \& Tester 1992, Roff et al. 1995), and detritivorous (Green et al. 1992), it is clear that copepod nauplii can also be quite omnivorous, as is now generally agreed for most adult copepods. Thus, previ-

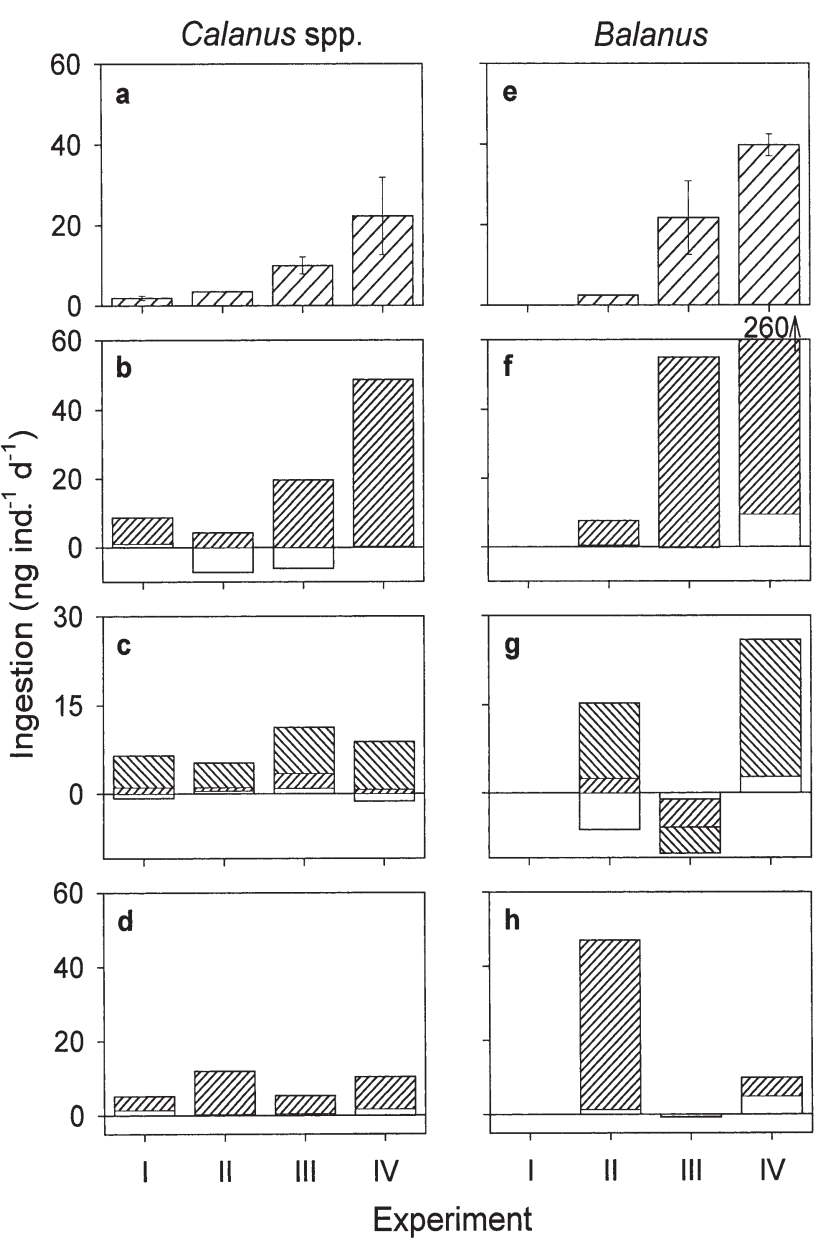

Fig. 10. Calanus spp. nauplii (a-d) and Balanus cf. crenatus nauplii (e-h). Ingestion of chlorophyll a (a, e), phytoplankton (b, f), ciliates $(c, g)$ and dinoflagellates $(d, h)$. Hatching patterns in $(a, e)$, $(\mathrm{b}, \mathrm{f}),(\mathrm{c}, \mathrm{g})$ and $(\mathrm{d}, \mathrm{h})$ correspond to those in keys to Figs $6,7,8$ and 9 , respectively. Note different scaleson $y$-axis

ous characterizations of copepod nauplii as primarily grazers upon small phytoplankton (see references in Turner 1984) are oversimplifications. Conversely, our results as well as successful laboratory culture of barnacle nauplii, suggest that they are primarily herbivorous, consuming mainly small phytoflagellates and diatoms (Anderson 1994 and references therein). Release of barnacle nauplii in nature also appears to be linked to phytoplankton blooms (Starr et al. 1991).

Following increased appreciation of the 'microbial loop' in pelagic food webs (Pomeroy 1974, Williams 1981, Azam et al. 1983), there has been mounting evidence for considerable intertwining of the 'microbial' and 'classical' food webs (reviewed by Turner \& Roff 1993). Although the importance of the pelagic microbial food web has been well-established for several 
Table 3. Calanus spp. Estimates (mean $\pm \mathrm{SD}$ ) of clearance, $F$, of specific prey categories (\% of surface water $\mathrm{d}^{-1}$ ) and ingestion, $I\left(\mathrm{ng} \mathrm{d}^{-1}\right)$ by the Calanus nauplii community, calculated using mean weight-specific clearances from grazing experiments and field biomass values in Disko Bay of the different prey categories (chlorophyll $a$, oligotrich ciliates, athecate dinoflagellates) and the copepod nauplii. $\mathrm{n}=$ number of stations where calculations were conducted. Range of values in parentheses

\begin{tabular}{|lccc|}
\hline & $F\left(\% \mathrm{~d}^{-1}\right)$ & $I\left(\mathrm{ng} \mathrm{d}^{-1}\right)$ & $\mathrm{n}$ \\
\hline Chlorophyll $a$ & $0.4 \pm 0.3$ & $4.5 \pm 10.3$ & 31 \\
& $(0.1-1.3)$ & $(0.1-55.3)$ & \\
Oligotrichs $<20 \mu \mathrm{m}$ & $1.8 \pm 1.7$ & $4.8 \pm 7.5$ & 13 \\
& $(0.2-5.4)$ & $(0.3-26.1)$ & \\
Oligotrichs $>20 \mu \mathrm{m}$ & $3.0 \pm 2.8$ & $73.6 \pm 76.8$ & 13 \\
& $(0.4-9.2)$ & $(2.5-248.5)$ & \\
Athecate $<20 \mu \mathrm{m}$ & $0.6 \pm 0.6$ & $10.9 \pm 12.0$ & 13 \\
& $(0.1-1.8)$ & $(0.3-44.6)$ & \\
Athecate $>20 \mu \mathrm{m}$ & $1.1 \pm 1.0$ & $78.6 \pm 78.8$ & 13 \\
& $(0.2-3.4)$ & $(1.8-257.4)$ & \\
\hline
\end{tabular}

decades for temperate and tropical waters, particularly in oligotrophic offshore habitats, evidence for a similar importance in Arctic ecosystems is much more recent (Andersen 1988, Nielsen \& Hansen 1995, Levinsen et al. 1999, and references therein). Partly for historical reasons, and supported by the 'cold ocean paradigm' (referenced in Rivkin et al. 1996), which infers that low temperature suppresses bacterial growth, thus reducing microbial loop activity, by far the most attention has been given to the classical food web and adult copepods of the genus Calanus in high northern latitude waters. Copepod nauplii are known to bridge the microbial and classical food webs by feeding upon picoplankton such as bacteria and small phytoplankton, which are generally considered to be inefficiently exploited by later-stage copepods. Subsequent transfer of portions of the microbial production to higher trophic levels occurs when nauplii are consumed by carnivorous zooplankton and planktivorous fishes. It is generally thought, however, that protozoans are more important than copepods (of any stage) in utilizing microbial production and conveying it to larger consumers in Arctic waters (Nielsen \& Hansen 1995, Hansen et al. 1996, 1999). Knowledge that copepod nauplii can facilitate trophic transfer through their predation on protozoans extends our understanding of potential pathways for mobility of nutrients and energy through pelagic food webs. It may also help explain why copepod nauplii often remain abundant, and as prey facilitate recruitment of upper-level consumers under conditions when availability of phytoplankton food appears to be insufficient (Ohman \& Runge 1994, Runge \& de Lafontaine 1996). Finally, it adds further to the recently-realized key role of ciliates and heterotrophic dinoflagellates in Disko Bay and other cold-water areas (Bjørnsen \& Kuparinen 1991, Burkill et al. 1995, Archer et al. 1996, Sherr et al. 1997, Levinsen \& Nielsen unpubl.).

In summary, when feeding in natural mixed plankton assemblages in Disko Bay during the post spring bloom stratified period, nauplii of Calanus spp. were feeding omnivorously to various degrees upon abundant nanoflagellates, as well as less-abundant diatoms, Myrionecta rubra, dinoflagellates and oligotrichous ciliates. However, the highest feeding rates by Calanus spp. nauplii were on oligotrichous ciliates. Conversely,

Table 4. Calanus spp. Ingestion (ng chlorophyll a or $\mathrm{C}^{-1} \mathrm{~d}^{-1}$ ) by nauplii community of various components of prey assemblages in Disko Bay, June 1997, calculated using field biomass values of the different types of prey and nauplii and the respective mean weight-specific clearances from grazing experiments. Relative contribution of protozoans (oligotrich ciliates + athecate dinoflagellates) to total ingestion (phytoplankton + protozoans) is shown in bold. Phytoplankton carbon calculated from chlorophyll a applying a C/chl a conversion factor of 44 (Nielsen et al. unpubl.)

\begin{tabular}{|c|c|c|c|c|c|c|c|c|}
\hline \multirow[t]{2}{*}{ Stn } & \multirow[t]{2}{*}{ Chl $a$} & \multirow{2}{*}{$\begin{array}{l}\text { Phytoplankton } \\
\text { carbon }\end{array}$} & \multicolumn{2}{|c|}{ Oligotrichs } & \multicolumn{2}{|c|}{ Athecate dinoflagellates } & \multirow{2}{*}{$\begin{array}{l}\text { Protozoans } \\
\text { (sum) }\end{array}$} & \multirow{2}{*}{$\begin{array}{c}\text { Ingestion } \\
\text { (\% protozoans }\end{array}$} \\
\hline & & & $<20 \mu \mathrm{m}$ & $>20 \mu \mathrm{m}$ & $<20 \mu \mathrm{m}$ & $>20 \mu \mathrm{m}$ & & \\
\hline 6 & 2.9 & 127 & 6 & 58 & 45 & 79 & 188 & 60 \\
\hline 10 & 1.5 & 65 & 0 & 3 & 0 & 5 & 8 & 11 \\
\hline 13 & 0.2 & 10 & 1 & 19 & 2 & 32 & 54 & 85 \\
\hline 15 & 1.0 & 44 & 2 & 11 & 3 & 37 & 53 & 55 \\
\hline 17 & 0.1 & 5 & 1 & 3 & 3 & 2 & 8 & 60 \\
\hline 24 & 0.2 & 8 & 1 & 19 & 12 & 30 & 62 & 89 \\
\hline 27 & 1.4 & 60 & 0 & 16 & 4 & 20 & 40 & 40 \\
\hline 31 & 2.9 & 126 & 26 & 249 & 23 & 257 & 555 & 81 \\
\hline 32 & 2.6 & 116 & 2 & 148 & 3 & 78 & 231 & 67 \\
\hline 33 & 4.1 & 181 & 3 & 134 & 15 & 204 & 355 & 66 \\
\hline 35 & 2.8 & 122 & 3 & 43 & 12 & 38 & 96 & 44 \\
\hline 37 & 55.3 & 2434 & 15 & 145 & 13 & 141 & 314 & 11 \\
\hline 39 & 1.5 & 67 & 3 & 109 & 6 & 99 & 217 & 76 \\
\hline
\end{tabular}


Table 5. Calanus spp. and Balanus cf. crenatus nauplii. Ingestion (ng $\mathrm{C}$ ind ${ }^{-1} \mathrm{~d}^{-1}$ ) of various components of the prey assemblage in grazing experiments conducted in Disko Bay, June 1997, calculated as explained in the 'Methods'. Mean relative contribution of protozoans (Myrionecta rubra + oligotrich ciliates + athecate dinoflagellates) to total ingestion of protists (phytoplankton + protozoans) shown in bold. Standard errors of triplicates in parentheses. Phytoplankton carbon calculated from chlorophyll a applying a C/chl a conversion factor of 44 (Nielsen et al. unpubl.). Ia to IVb: expt numbers; (-) only 1 replicate counted

\begin{tabular}{|c|c|c|c|c|c|c|c|}
\hline \multirow{2}{*}{ Prey } & \multicolumn{4}{|c|}{ Calanus spp. nauplii } & \multicolumn{3}{|c|}{ Balanus cf. crenatus nauplii } \\
\hline & Ia & IIa & IIIa & IVa & IIb & IIIb & $\mathrm{IVb}$ \\
\hline Myrionecta rubra & $-0.8(0.1)$ & $0.5(0.3)$ & $0.9(0.3)$ & $-1.3(1.4)$ & $-6.2(1.9)$ & $-1.1(2.2)$ & $2.7(2.1)$ \\
\hline Oligotrichs $<20 \mu \mathrm{m}$ & $1.1(0.2)$ & $0.6(0.1)$ & $2.5(0.2)$ & $0.7(0.1)$ & $2.5(0.6)$ & $-4.7(2.7)$ & $0.1(0.5)$ \\
\hline Oligotrichs $>20 \mu \mathrm{m}$ & $5.4(0.8)$ & $4.2(0.5)$ & $7.8(1.5)$ & $8.1(4.3)$ & $12.7(3.7)$ & $-4.4(2.8)$ & $23.1(9.7)$ \\
\hline Athecate $<20 \mu \mathrm{m}$ & $1.5(0.1)$ & $0.4(0.1)$ & $0.6(0.2)$ & $1.7(0.1)$ & $1.3(0.5)$ & $-0.7(0.9)$ & $4.7(1.5)$ \\
\hline Athecate $>20 \mu \mathrm{m}$ & $3.6(0.6)$ & $11.4(0.9)$ & $4.7(2.1)$ & $8.6(0.6)$ & 45.7 (3.9) & $-0.1(0.7)$ & $5.1(3.2)$ \\
\hline Protozoans (sum) & $10.8(1.7)$ & $17.1(1.8)$ & $16.5(4.4)$ & $17.8(6.5)$ & $56.0(10.6)$ & $-11.1(9.3)$ & $35.7(17.0)$ \\
\hline Phytoplankton & $84.0(23.3)$ & $151.4(-)$ & $438.7(92.4)$ & $979.0(424.6)$ & $105.6(-)$ & $956.1(403.9)$ & $1750.8(120.1)$ \\
\hline$\%$ protozoans & 11.4 & 10.1 & 3.6 & 1.8 & 34.6 & -1.2 & 2.0 \\
\hline
\end{tabular}

barnacle nauplii Balanus cf. crenatus fed primarily upon phytoplankton, with lower rates of feeding on ciliates and dinoflagellates. The observation of comparatively higher feeding upon oligotrichous ciliates by copepod nauplii is similar to results for later-staged copepods in many studies. Also, primarily herbivorous feeding by barnacle nauplii is in agreement with numerous observations in studies using laboratory diets, but there is apparently such limited information on feeding by barnacle nauplii on natural plankton assemblages that further comparisons are precluded.

Acknowledgements. We thank the crew of the 'Adolf Jensen' for able seamanship and help during sampling, and Birgit Søborg, Frank Jensen and Siz Madsen for excellent technical assistance. We are grateful for the constructive comments on an earlier version of this paper by Thomas Kiørboe, Per Juel Hansen and Peter Verity. This investigation was supported by The Danish National Research Council, Project 9501038.

\section{LITERATURE CITED}

Andersen P (1988) The quantitative importance of the 'microbial loop' in the marine pelagic: a case study from the North Bering/Chukchi Sea. Arch Hydrobiol 31: $243-251$

Anderson DT (1994) Barnacles. Structure, function, development and evolution. Chapman \& Hall, London

Archer SD, Leakey RJG, Burkill PH, Sleigh MA (1996) Microbial dynamics in coastal waters of East Antarctica: herbivory by heterotrophic dinoflagellates. Mar Ecol Prog Ser 139:239-255

Azam F, Fenchel T, Field JG, Gray JS, Meyer-Reil LA, Thingstad F (1983) The ecological role of water-column microbes in the sea. Mar Ecol Prog Ser 10:257-263

Berggreen U, Hansen B, Kiørboe T (1988) Food size spectra, ingestion and growth of the copepod Acartia tonsa during development: implications for determination of copepod production. Mar Biol 99:341-352

Bjørnberg T (1984) The rejected nauplius, a commentary. In: Schriever G, Schminke HK, Shih CT (eds) Proc Int Conf Copepoda, Ottawa, Canada, Syllogeus Series No. 58. National Museum of Canada, Ottawa, p 232-236
Bjørnsen PK, Kuparinen J (1991) Growth and herbivory by heterotrophic dinoflagellates in the Southern Ocean, studied by mesocosm experiments. Mar Biol 109:397-405

Burkill PH, Edwards ES, Sleigh MA (1995) Microzooplankton and their role in controlling phytoplankton growth in the marginal ice zone of the Bellinghausen Sea. Deep-Sea Res II 42:1277-1290

Fessenden L, Cowles TJ (1994) Copepod predation on phagotrophic ciliates in Oregon coastal waters. Mar Ecol Prog Ser 107:103-111

Frost BW (1972) Effects of size and concentration of food particles on the feeding behavior of the marine planktonic copepod Calanus pacificus. Limnol Oceanogr 17:805-815

Gifford DJ, Dagg MJ (1991) The microzooplankton-mesozooplankton link: consumption of planktonic protozoa by the calanoid copepods Acartia tonsa Dana and Neocalanus plumchrus Murukawa. Mar Microb Food Webs 5:161-177

Green EP, Harris RP, Duncan A (1992) The production and ingestion of faecal pellets by nauplii of marine calanoid copepods. J Plankton Res 14:1631-1643

Hansen BW, Christiansen S, Pedersen G (1996) Plankton dynamics in the marginal ice zone of the central Barents Sea during spring: carbon flow and structure of the grazer food chain. Polar Biol 16:115-128

Hansen BW, Nielsen TG, Levinsen H (1999) Plankton community structure and carbon cycling on the western coast of Greenland during the stratified situation. III. Mesozooplankton. Aquat Microb Ecol 16:233-249

Hansen PJ, Bjørnsen PK, Hansen BW (1997) Zooplankton grazing and growth: scaling within the $2-2000 \mu \mathrm{m}$ body size range. Limnol Oceanogr 42:687-704

Hopcroft RR, Roff JC (1998) Zooplankton growth rates: the influence of size in nauplii of tropical marine copepods. Mar Biol 132:87-96

Hygum BH, Rey C, Hansen BW (2000) Growth and development rates of Calanus finmarchicus (Gunnerus) nauplii during a diatom spring bloom. Mar Biol 136:1075-1085

Jespersen AM, Christoffersen K (1987) Measurements of chlorophyll-a from phytoplankton using ethanol as extraction solvent. Arch Hydrobiol 109:445-454

Jonsson P, Tiselius P (1990) Feeding behavior, prey detection and capture efficiency of the copepod Acartia tonsa feeding on planktonic ciliates. Mar Ecol Prog Ser 60:35-44

Kiørboe T, Sabatini M (1995) Scaling of fecundity, growth and development in marine planktonic copepods. Mar Ecol Prog Ser 120:285-298

Lang WH (1979) Larval development of shallow water barna- 
cles of the Carolinas (Cirripedia: Thoracica) with keys to naupliar stages. NOAA Tech Rep NMFS Circ 421:1-39

Lang WH, Ackenhusen-Johns A (1981) Seasonal species composition of barnacle larvae (Cirripedia: Thoracica) in Rhode Island waters, 1977-1978. J Plankton Res 3:567-575

Levinsen H, Nielsen TG, Hansen BW (1999) Plankton community structure and carbon cycling on the western coast of Greenland during the stratified situation. II. Heterotrophic dinoflagellates and ciliates. Aquat Microb Ecol 16: 217-232

Levinsen H, Turner JT, Nielsen TG, Hansen BW (2000a) On the trophic coupling between protists and copepods in Arctic marine ecosystems. Mar Ecol Prog Ser 204:65-77

Levinsen H, Nielsen TG, Hansen BW (2000b) Annual succession of marine pelagic protozoans in Disko Bay, West Greenland, with emphasis on winter dynamics. Mar Ecol Prog Ser 206:119-134

Madsen SD, Nielsen TG, Hansen BW (2001) Annual population development and production by Calanus finmarchicus, C. glacialis and C. hyperboreus in Disko Bay, western Greenland. Mar Biol 139:75-93

Marshall SM, Orr AP (1955) The biology of a marine copepod Calanus finmarchicus (Gunnerus). Oliver \& Boyd, Edinburgh

McKinnon AD (1996) Growth and development in the subtropical copepod Acrocalanus gibber. Limnol Oceanogr 41:1438-1447

Merrell JR, Stoecker DK (1998) Differential grazing on protozoan microzooplankton by developmental stages of the calanoid copepod Eurytemora affinis Poppe. J Plankton Res 20:289-304

Moyse J (1963) A comparison of the value of various flagellates and diatoms as food for barnacle larvae. J Cons Int Explor Mer 28:175-187

Nakamura Y, Turner JT (1997) Predation and respiration by the small cyclopoid copepod Oithona similis: how important is feeding on ciliates and heterotrophic flagellates? J Plankton Res 19:1275-1288

Nielsen TG, Hansen BW (1999) Plankton community structure and carbon cycling on the western coast of Greenland during the stratified summer situation. I. Hydrography, phytoplankton and bacterioplankton. Aquat Microb Ecol 16:205-216

Nielsen TG, Hansen BW (1995) Plankton community structure and carbon cycling on the western coast of Greenland during and after the sedimentation of a diatom bloom. Mar Ecol Prog Ser 125:239-257

Ohman MD, Runge JA (1994) Sustained fecundity when phytoplankton resources are in short supply: omnivory by Calanus finmarchicus in the Gulf of St. Lawrence. Limnol Oceanogr 39:21-36

Pierce RW, Turner JT (1992) Ecology of planktonic ciliates in marine food webs. Rev Aquat Sci 6:139-181

Rivkin RB, Anderson MR, Lajzerowicz C (1996) Microbial processes in cold oceans. I. Relationship between temperature and bacterial growth rate. Aquat Microb Ecol 10:243-254

Pomeroy LR (1974) The ocean's food web, a changing paradigm. BioScience 24:499-504

Roff JC, Turner JT, Webber MK, Hopcroft RR (1995) Bacterivory by tropical copepod nauplii: extent and possible significance. Aquat Microb Ecol 9:165-175

Runge JA, de Lafontaine Y (1996) Characterization of a pelagic food web in the northern Gulf of St. Lawrence: the larval redfish-Calanus spp.-microplankton interaction. Fish Oceanogr 5:21-37

Editorial responsibility: Otto Kinne (Editor),

Oldendorf/Luhe, Germany
Sherr EB, Sherr BF, Fessenden L (1997) Heterotrophic protists in the Central Arctic Ocean. Deep-Sea Res II 44: 1665-1682

Starr M, Himmelman JH, Therriault JC (1991) Coupling of nauplii release in barnacles with phytoplankton blooms: a parallel strategy to that of spawning in urchins and mussels. J Plankton Res 13:561-571

Stoecker DK, Capuzzo JM (1990) Predation on Protozoa: its importance to zooplankton. J Plankton Res 12:891-908

Stoecker DK, Egloff DA (1987) Predation by Acartia tonsa on planktonic ciliates and rotifers. J Exp Mar Biol Ecol 110: 53-68

Stone CJ (1989) A comparison of algal diets for cirripede nauplii. J Exp Mar Biol Ecol 132:17-40

Strathmann RR (1967) Estimating the organic carbon content of phytoplankton from cell volume or plasma volume. Limnol Oceanogr 12:411-418

Tiselius P (1989) Contribution of aloricate ciliates to the diet of Acartia clausi and Centropages hamatus in coastal waters. Mar Ecol Prog Ser 56:49-56

Turner JT (1982) The annual cycle of zooplankton in a Long Island estuary. Estuaries 5:261-274

Turner JT (1984) The feeding ecology of some zooplankters that are important prey items of larval fish. NOAA Tech Rep NMFS 7:1-28

Turner JT (1994) Planktonic copepods of Boston harbor, Massachusetts Bay and Cape Cod Bay, 1992. Hydrobiologia 292/293:405-413

Turner JT (2000) Feeding ecology of marine copepods: an overview of recent studies and emerging issues. In: Hwang JS, Wang CH, Chan TY (eds) Proceedings of the International Symposium on Marine Biology in TaiwanCrustaceans and Zooplankton: Taxonomy, Ecology and Living Resources, 26-27 May, 1998, National Taiwan Museum, Taipei. Special Publication Series 10:37-57

Turner JT, Granéli E (1992) Zooplankton feeding ecology: grazing during enclosure studies of phytoplankton blooms from the west coast of Sweden. J Exp Mar Biol Ecol 157: $19-31$

Turner JT, Roff JC (1993) Trophic levels and trophospecies in marine plankton: lessons from the microbial food web. Mar Microb Food Webs 7:225-248

Turner JT, Tester PA (1992) Zooplankton feeding ecology: bacterivory by metazoan microzooplankton. J Exp Mar Biol Ecol 160:149-167

Uye SI (1982) Length-weight relationships of important zooplankton from the Inland Sea of Japan. J Oceanogr Soc Jpn 38:149-158

Uye SI, Kasahara S (1983) Grazing of various developmental stages of Pseudodiaptomus marinus (Copepoda: Calanoida) on naturally occurring particles. Bull Plankton Soc Jpn 30: 147-158

Webber MK, Roff JC (1995) Annual structure of the copepod community and its associated pelagic einvronment off Discovery Bay, Jamaica. Mar Biol 123:467-479

Williams PJ leB (1981) Incorporation of microheterotrophic processes into the classical paradigm of the planktonic food web. Kieler Meeresforsch Sonderh 5:1-28

Williams R, Conway DVP, Collins NR (1987) Vertical distributions of eggs, nauplii and copepodites of Calanus helgolandicus (Copepoda: Crustacea) in the Celtic Sea. Mar Biol 96:247-252

Wiadnyana NN, Rassoulzadegan F (1989) Selective feeding of Acartia clausi and Centropages typicus on microzooplankton. Mar Ecol Prog Ser 53:37-45

Submitted: September 18, 2000; Accepted: January 9, 2001

Proofs received from author(s): October 8, 2001 